\title{
The Role of Participation in Urban Landscape Planning in Yokohama: The Success of the Takashima Central Park Project
}

\author{
Marco Akira Klebel
}

\begin{abstract}
In Japan, citizens' participation in urban planning is called machizukuri. This kind of cooperation between citizens and city administration in urban planning appeared in the 1970s, as a countermovement to the traditional top-down urban planning called toshikeikaku of the 1960s. Municipal city planning increasingly encouraged machizukuri projects, allowing citizens to participate in planning activities. The City of Yokohama in Kanagawa Prefecture promoted innovative methods of participation. From the 'Letters to the Mayor' in the late 1960s to current programmes, the City of Yokohama established many support measures for machizukuri activities and in the 1990s the administration approved the engagement of citizens as an important management tool, as seen in the City Construction Project for the Citizens of Yokohama. One contribution to this project is the Takashima Central Park Project, which started in 2008 and which is considered by many critics as a very successful participation project.

This paper focuses on the questions of how far the Takashima Central Park Project was successful and what the reasons for success or unspoken failure were by referring to the theories of the German political scientist Angelika Vetter and the German political sociologist Brigitte Geißel. The research is based on qualitative interviews with some of the people involved, such as citizens, planners and administrative personnel. The article will identify the various aspects of the complex variable 'success' and their interdependence.
\end{abstract}

Keywords: machizukuri, park planning, participation, urban planning, Yokohama

Klebel, Marco Akira. "The Role of Participation in Urban Landscape Planning in Yokohama: The Success of the Takashima Central Park Project." In Vienna Journal of East Asian Studies, Volume 3, eds. Rüdiger Frank, Ingrid Getreuer-Kargl, Lukas Pokorny and Agnes Schick-Chen. Vienna: Praesens Verlag, 2012, pp. 33-72. https://doi.org/10.2478/vjeas-2012-0002 


\section{Introduction}

In 2008, about 89 percent of the Japanese population lived in cities with more than 30,000 inhabitants (NTN 2009: 40); the environment of many Japanese is thus affected by urban structures. To improve the quality of life in a city, the participation of residents - as the smallest part of an urban structure - plays a very important role, because they are experts in the needs engendered by everyday experience. So who knows better about the conditions and needs of such experience than the occupants or residents themselves? Citizens' participation in urban development and planning disciplines is a relatively recent phenomenon. Up to the 1970s, urban planning in Japan was a discipline for experts, but through protest movements on the part of dissatisfied citizens, a new type of city planning, where citizens are able to take action, was established over time. How far are these participatory projects really successful? To answer this question, I examined the Takashima Central Park Project as a case study. This park is located in the Minato Mirai $21 \mathrm{area}^{1}$ in Yokohama 横浜, and is approximately 1.4 hectares in size. It was planned by citizens two times; in 2003 and in 2008, each time with different methods of participation. The first time was between 2003 and 2004 and the second between 2008 and 2010. In Japanese literature this project is stated to be a very successful participation project. However, was the project successful for everyone?

First I want to deliver insight into the history of urban planning and the form of participation in urban/city planning called machizukuri まちづくり in Japan. Then I will introduce the Japanese neighbourhood associations, known as chōnaikai 町内会. Subsequently I will write about the machizukuri in Yokohama and the participationpromoting projects of the City of Yokohama, especially the City Construction Project. My analysis of the actual Takashima Central Park Project 高島中央公園プロ ジェクト is based on the theories of the German political scientist Angelika Vetter and the political sociologist Brigitte Geißel, and will answer the question about the successfulness of the project.

This paper is based on an inductive approach. After a study of Japanese and German secondary literature on participation, urban planning and success criteria, primary resources such as reports and transcripts from the City of Yokohama on the

Acknowledgment: I am indebted to Tsukada Yōichirō, Naitō Noriko and Matsumoto Michio who have generously permitted the reproduction of photographs and maps.

1 The Minato Mirai 21 area is about 186 hectare in size and is located between the Nishi District 西区 and the Kannai District 関内. From the Meiji era (1868-1912) this part of the city was built through landfill and was a basic part of Yokohama harbour (YTKK MM21 1989: 23). However, since the 1970s the significance of this old harbour has been shrinking (TKSK 2004: sankō 6), and Asukata Ichio 飛鳥田 一雄, the former mayor of Yokohama, decided to utilise the area to extend the city (ZHY 2009: 326). In the 1980s this part of the old harbour was turned into a waterfront development area and a new part of the city was planned for about 190,000 workplaces and 10,000 residents (YTKK MM21 1989: 22). 
Takashima Central Park Project were analysed. Between July 27 and August 30, 2010 qualitative interviews with the people involved, i.e. citizens, planners and administrative staff, were carried out. The interviewees were:

- Minakuchi Hidehiko, deputy director of the Department of chiiki machizukuri in the Department of City Organisation in Yokohama

- Horiuchi Hiroyuki, deputy director of the Department of chiiki machizukuri in the Department of City Organisation in Yokohama

- Tsukada Yōichirō, assistant head of the Department for the Promotion of Minato Mirai 21

- Ōkage Naoko, assistant head of the Department for District machizukuri in the Department of City Organisation in Yokohama

- Sakai Kazuhiro, deputy director for parks in the city centre in the Departmental Environmental Planning Office in Yokohama

- Naitō Noriko, landscape architect, and participant as a citizen in the Takashima Central Park Project in 2008

- Matsumoto Michio, architect and editor in chief of the Information Management Office in an architecture corporation and participant as a citizen in the Takashima Central Park Project in 2008. Representative of the Takashima Central Park Gardening Club since 2010

- Mr and Mrs Uchida (the couple's surname has been changed at the request of the interviewees in order to ensure anonymity), residents living next to the Takashima Central Park

- Mrs Amamiya, who took part in the workshops in 2003 as a citizen; her statement is taken from a field report. Age and occupation are unknown

- Mrs Shimizu, who took part in the workshops in 2003 as a citizen; her statement is taken from a field report. Age and occupation are unknown

\section{Urban planning in Japan}

Japanese city planning is based on ancient Chinese town planning principles, where grid and rectangular shapes were characteristic. The former capital cities of Japan, Nara 奈良 (Heijō-kyō 平城京) and Kyōto 京都 (Heian-kyō 平安京) from the 8th century exhibit elementary forms of the former Chinese capital city Ch'ang-an 長安. Furthermore, the so-called castle towns ${ }^{2}$ are typical city forms from ancient Japan in the Tokugawa period 徳川時代 and the Edo period 江戸時代 (1603-1868), respectively.

2 In Japanese called jōka-machi 城下町. 
In Japan the notion of urban planning is called toshikeikaku 都市計画. The concept first appeared in the Tōkyō Municipal Ordinance in 1888, in terms of a technocratic top-down planning by experts (Hohn 2000: 100). During the Meiji era (18681912) city planning was characterised by urban restructuring and urban renewal, to modernise the old castle towns (Hohn 2000: 41). Infrastructural innovations like railways and harbour areas were accounted as the basic of industrialisation (Flüchter 1978: 13). The strong drive towards industrialisation effected by the textile industry from 1868 caused rapid urbanisation, and between 1891 and 1920 the number of cities with more than 100,000 citizens rose from six to sixteen (Hohn 2000: 48-49). Urban planning in the Meiji era was furthermore characterised by infrastructure planning, the improvement of fire protection requirements and prestigious projects in Western style. City planning was exploited as a demonstration of governmental power and for the improvement of economic modernisation, as, for example, in the Ginza district in Tōkyō.

In 1919, the first town planning act (Toshi keikaku-hō 都市計画法) was enacted. It controlled the expanding settlements, structural compaction and conflicts of land use brought about by industry. The planning processes were embedded in a centralising planning bureaucracy and Western planning instruments like the reallocation of building land (Tochi kukaku seiri 土地区画整理), a code for the alignment of buildings (Kenchiku-sen seido 建築潜制度) and a zoning plan for land use (Yōto chiiki seido 用途地域制度) were introduced. In 1920, this first town planning act was applied in cities like Tōkyō 東京, Ōsaka 大阪, Kōbe 神戸, Kyōto, Nagoya 名 古屋 and Yokohama. In all other cities and villages the act was applied in 1933 (Hohn 2000: 51). According to this law town planning was a matter for the state and not for the prefectures or municipalities (Hohn 2000: 51). The land use zoning plan was strongly criticised for its lack of detail, but it was one of the most important instruments in city planning in Japan until 1968. In addition, Flüchter mentions that a lack of commitment and the partial ignoring of plans from the town planning authority led to an ineffective control of urbanisation and urban development as well as of land use (1978: 27). As part of the reconstruction after the devastating Kantō earthquake of 1923, many citizens were involved and protested against the floor plan assignment of the government. Town planning was no longer considered as a technical, structural and artistic discipline carried out by experts, but was also seen as dependent on political interests (Hohn 2000: 53).

In 1950 the Land Development Law (Kokudo sōgō kaihatsu-hō 国土総合開発 法) was enacted, in which the development of industry and economy had a major role (Satō 2007: 22). Urban development in the post-war period in Japan was characterised by reconstruction. From 1949, budget cuts in state subsidies for reconstruction projects led to drastic cost-cutting measures. Since no adequate planning tools were available to control urban development, funds for public infrastructure projects were missing, and the purchase of land was difficult because of high land prices. 
Between 1951 and 1955, an extremely deregulated style of urban development, dominated by private and capital interests, took hold. (Hohn 2000: 66-70) After World War II, no reforms of the old urban planning system were carried out, leaving Japan in a period of high economic growth without adequate planning laws (Hohn 200: 72). In this phase of high growth, the infrastructure and the economy were the main aspects of urban development. Human wellbeing in cities was played down in favour of economic development (YTKK 1983: 92). The population suffered from serious air and water pollution, noise pollution from industry and transport, a lack of green spaces, and a lower standard in their living environment. In the second half of the 1960s, a change in values in Japanese society occurred. The priority of quantitative economic growth gave way in favour of qualitative values like social welfare, environmental protection, and an improvement in the living environment (Tanaka 1989: 141).

In June 1968, a new town planning act was passed, after which there was a change of planning skills. Decision-making power shifted from the national down to the prefectural and municipal level. This change was an important step towards decentralisation (Hohn 2000: 82).

\section{Machizukuri-the beginning of participation in urban planning in Japan}

Based on German regulations, the new Japanese town planning act of 1968 contained a legal determination of formal participation, which led to a process of democratisation in town planning. However, the intensity of participation was very low, and only public hearings were provided. According to the law, counties and municipalities allowed citizens to submit written comments on planning proposals before decisions were made (Flüchter 1978: 27-33). These public hearings and information sessions at the planning stage of development were optional. The statutory public participation provided only for the right to comment and the statement had to be submitted within two weeks after the setting of the draft plan. According to Ishida, the Ministry of Construction brought numerous city planning decisions forward shortly before the law came into force on June 14, 1969, as massive claims by prefectures and municipals had already been filed (Ishida 1987: 308).

By the 1970s, machizukuri had started as a countermovement to toshikeikaku, prompted by numerous negative experiences among local residents caused by unacceptable living conditions, pollution, and the loss of historic buildings. The movement was based on a strengthened civic engagement with the aim of creating liveable cities in Japan (Hohn 2000: 100) and it developed through a process of transformation of urban planning in the wake of democratisation. Gradually the participation euphoria of Western countries spread to Japan (Vogt 2001: 71). Specifically, the 
era of machizukuri began in 1962 with citizen protests in the City of Nagoya. The new term machizukuri was initially written as follows: 街づくり. ${ }^{3}$ This notation of the 1960s implies rejection, criticism and protest against the technocratic urban planning system called toshikeikaku. In the 1970s, civic participation gradually assumed an increasingly important role in Japan, where the process shifted towards cooperative approaches between citizens and government. Citizens began to launch their own initiatives to improve the living environment, which was considered as a public campaign, as opposed to a protest. In order to mark a break with the former negative connotations of the term machizukuri written with the characters 街づくり, the characters were changed in $⿴ 囗 十 丁 亍) く り .{ }^{4}$ At the same time the official municipal city planning authority supported, encouraged, and initiated these new approaches to planning, where citizens could participate actively (Hohn 2000: 100). Since the 1980s, machizukuri is written only with hiragana characters まちづくり and includes the creation of positive interpersonal relationships, where concrete urban projects were implemented with closer co-operation between government and citizens (Vogt 2001: 74). Gradually, the political representatives enacted machizukuri statutes and encouraged directives to support machizukuri movements. A major step was taken in March 1998 with the enactment of the NPO $^{5}$ Act (NPO-hō), under which residential organisations were given the opportunity of legal recognition as charitable non-profit organisations. Machizukuri operates at the urban micro-level, where residents of urban districts, kumin 区民, or people from a residential environment, jūmin 住民, support the urban projects (Hohn 2000: 32). It does not mean that toshikeikaku has been replaced by machizukuri. Vogt mentions that the old concept of toshikeikaku still exists today and has not been replaced by the new planning culture of machizukuri, but has been enhanced with additional options (Vogt 2001:70).

In 1992, a modification of the City Planning Law of 1968 promoted the anchoring of decision-making powers in matters of urban planning at the local level; these bind all municipalities to establish a master plan (Vogt 2001: 94). Public participation in urban planning projects was legally binding for the first time (Vogt 2001: 45). In addition to the right of statement and decision-making at the local level (Hohn 2000: 107), this modification of the law was a great contribution to the decentralisation of administration (Satō 2007: 23). Through the establishment of this municipal

3 街 (machi) is the kanji (Chinese character) for city or street and is read kai or gai in the Sino-Japanese reading and machi in the pure Japanese reading; the hiragana character づくり is read zukuri and means to 'do', 'make', 'create'. If you translate it literally, machizukuri means 'create the city'.

4 町 (machi) is the kanji for city and is read chō in the Sino-Japanese reading and machi in the pure Japanese reading.

5 NPO means non-profit organisation. 
master plan (Shi-chō-son ${ }^{6}$ no toshikeikaku ni kansuru kihonteki hōshin 市町村の都 市計画に関する基本的方針), public participation at the planning preparation stage became mandatory, thereby strengthening participation in statutory planning preparation processes (Hohn 2000: 107). This early public participation at the time of the preparation of a draft plan was prescribed as public hearings, information events (Hohn 2000: 116), postcard surveys and exhibitions, all of them incorporating concerns and suggestions (Vogt 2001: 94). This duty of drawing up a master plan for all municipalities is still valid and has linked the citywide development planning with machizukuri at city district level (Hohn 2000: 116). In early 2000, more than 600 municipalities possessed such a master plan (TKCS 2000: 5).

\section{Chōnaikai in Japan—-the core unit of a community}

Chōnaikai 町内会 are neighbourhood associations which have a close relationship with local government and are regarded as a social 'link' between citizens and city administration. Members of a chōnaikai organise cleaning campaigns of green spaces and parks, information meetings on waste disposal methods, advise on issues of social care, and co-ordinate various events and traditional festivals (matsuri 祭り). The roots of chonaikai lie in the feudal society of the Edo period (Hohn 2000: 517518).

In a chōnaikai or jichikai ${ }^{7}$ 自治会, a household is counted, not the individual citizen. The chairpersons are selected by agreement during the meetings, not directly and anonymously by the residents (Hohn 2000: 516). The structures of chonaikai depend on the respective sizes and aims, and of course on the environment and history of each area, but they generally have a hierarchical structure (YSSK 2002: 6). Multiple households form a group called han 班 and several han form one chōnaikai. Each han has a group leader called the han-chō 班長, who collects the membership fees, distributes advertisements and leaflets to the relevant households or sends out circular letters. Depending on the chonaikai, the respective fields vary with the deputies and supervisory boards and in some cases, they even can make policy decisions (YSSK 2002: 6). The chonnaikai deal with various issues, but the topics always affect the residents and the local area. These neighbourhood associations are thus a very interesting method of civil administration with citizen participation. Even small town construction projects, machizukuri projects or projects for park planning and park management fall within the field of activity of the chonaikai (YSSK 2002: 28).

6 The shi-cho-son, or municipalities, are fundamental regional authorities in Japan and consist of districts $(k u)$ and residents (jümin), which are ensured autonomy according to the Japanese Constitution (Harada 1972: 566).

7 Jichikai are self-governed corporate bodies. A chōnaikai is a kind of jichikai (Murahashi 2009: 148). 
But it is questionable to what extent projects and decisions are made and implemented democratically.

Specifically, the chōnaikai are often criticised because of a gender imbalance, both in quantitative terms, in numbers, as well as in the qualitative and content approach of the respective areas of responsibility. Although the number of female neighbourhood association leaders, managers, or members is increasing, these organisations are still mainly dominated by men (Murahashi 2009: 148). The leaders are often older men, whose families are deeply rooted in the neighbourhood (Hohn 2000: 516). This situation often leads to conservative and entrenched structures that are often very hierarchical and seniority-based. Matsumoto Michio ${ }^{8}$ 松本道雄, editor in chief in the Information Management Office in an architecture corporation, when interviewed, also criticised the difficulty of access to the chonaikai for 'newcomers', especially when the old structures were built on a long tradition. Deadlocked and hierarchical structures often prevented the emergence of innovative ideas (Matsumoto 2010). For these reasons, Mr Matsumoto did not engage in local citizens' movements like machizukuri projects in his former neighbourhood, because he was not satisfied with the existing social structure in the chonaikai. Nevertheless, we must not forget that the largest participation successes were achieved especially in such districts, where people feel at home and rooted through a long period of residence (Hohn 2000: 530). Therefore, a reformed system of chōnaikai would promote equitable public participation. To democratise and reform the system, representatives should be determined by secret ballots and membership should be based on individuals rather than households, and the 'power of the old men' should be broken. Nevertheless, a reform of the chonaikai system is very unrealistic, because many younger people are unwilling to invest their personal free time in representing the interests of the public in the neighbourhood. As retirees tend to have more free time than younger, employed people, there is often a one-sided age structure. Moreover, chōnaikai work is regarded as a burden in many places (Hohn 2000: 530).

Although membership in a neighbourhood association is based on the principle of voluntarism, the absolute majority of Japanese households belong to a chonnaikai (Hohn 2000: 517). The voluntary nature of membership is therefore called into question. In Yokohama, for example, the accession rate of households to a chonaikai of 87.6 percent is relatively high. From the total of 1,412,547 households in Yokohama, $1,237,558$ households belonged to a chonaikai in 2002. According to a survey by the Office of the City of Yokohama, in 2002, 2,830 chonnaikai were counted in a population of approximately 3.6 million inhabitants (YSSK 2002: 4). Ōkage Naoko 大蔭直 子, assistant head of the Department for District machizukuri (chiiki machizukuri 地 域まちづくり) in the Department of City Organisation in Yokohama 横浜市都市

8 Matsumoto Michio is also a representative of the Takashima Central Park Gardening Club and works as an architect. 
整備局, added in an interview that the percentage varies between all eighteen districts and depends on the respective counties. In new cities or new suburbs (New Towns), for example, in the northern part of Yokohama, the accession number is very low. In the southern and central parts of Yokohama, where older urban structures can be found, the accession number is very high (Ōkage 2010). In 1997, the accession figure was almost 90 percent (Kozawa and Akimoto 1997: 88). On average, ten to fifteen households form one han or kumi 組 in Yokohama (YSSK 2002: 6) and about 26 han one chōnaikai (Kozawa and Akimoto 1997: 88). Critical aspects like an unequal gender distribution or the homogeneous age structure of chairpersons of a chōnaikai are also found in Yokohama. According to the survey of the Civil Office of the City of Yokohama in 2002, 65.7 percent of chairpersons of chōnaikai in Yokohama were over 60 years and only 5.5 percent were 20 to 30 years old. In the same survey, 83.1 percent of the chairpersons were men and only 8.5 percent were women; the remaining 8.4 percent reported no sex (YSSK 2002: 7). Nevertheless, the chōnaikai or jichikai is still seen as the spearhead of the whole administrative system of the City of Yokohama and plays an important role as a representative citizen body, which is legitimised and addressed by the administration (Tsuchiya 2009: 173).

\section{Machizukuri in Yokohama}

The City Administration of Yokohama established a system of citizen participation very early on, in 1963, the system of 'Letters to the Mayor' (shicho e no tegami 市 長への手紙) (Geocities 2010). Furthermore, the Registration Office of the district administration, the Counselling Office for residents and independent Citizens' Consultations (kumin kaigi 区民会議) offered informative meetings for citizens. Through these systems of participation the needs and view of citizens were recorded by the city administration. In addition, the administration established community centres (kumin sentā 区民センター) or architectural commissions and held workshops to solicit the opinions of citizens regarding city planning and open space planning (Murahashi 2009: 148). To inform as many citizens as possible, the City of Yokohama focused on promoting public and neighbourhood information (YTKK 1983: 137). However, these surveys of public opinion were not binding. The numerous independent citizens' initiatives (shimin katsudō 市民活動) can be seen as an indicator of the lack of implementation of citizen wishes. Later, the city government

9 To understand the opinions and attitudes of the citizens better, a system was established where every citizen could send a sealed letter or postcard directly to the mayor. For this reason, forms with the title 'Letters to the Mayor' were provided in public facilities such as district town halls, health centres, district centres or in important buildings such as banks and railway stations. The postage was free of charge (YTKK 1983: 137). 
of Yokohama began to pick up on civil commitment and started to seek the participation of members of the jichikai or chōnaikai for road and facility construction (Murahashi 2009: 148). The high rate of neighbourhood association, reaching 90 percent in some cases (Tsuchiya 2009: 173), suggested a wide range of participants. At the beginning of the 1990s, the administration in Yokohama noted that, because of an imbalance in gender and age distribution, the needs and desires of citizens could not be explored adequately by involving only chōnaikai or jichikai (Tsuchiya 2009: 173). The Department of City Planning (Toshi seibi-kyoku 都市整備局) in Yokohama therefore established the scheme of 'support for autonomous machizukuri activities' (jishū-teki na machizukuri katsudo e no shien 自習的なまちづくり 活動への支援) in 1991. This supporting instrument was renamed in 1997 'support for machizukuri activities' (machizukuri katsudo e no shien まちづくり活動への支 援) and at the same time, plans and programmes for subsidies to individual citizens groups were triggered. These two initiatives were the basis for further city planning projects led by partnership. In 1994 the Administrative Procedure Act (Gyōsei tetsuzuki-hō 行政手続き法) and seven years later, the Law to Advance Decentralisation (Chihō bunken suishin-hō 地方分権推進法), and the NPO Act were enacted at state level. This led to an acceleration of social and economic system reforms. Topics like welfare for the elderly, education, and environmental protection were incorporated into the policies of urban planning and machizukuri (Murahashi 2009: 149).

In this early phase of co-operation between government and citizens, from 1991 to 1996, the concept of civil commitment received support not only from the Department of City Planning, but also from the Environmental Protection Agency (Kankyō hozen-kyoku 環境保全局), which supported programmes for environmental protection activities (kankyō hozen katsudō shien 環境保全活動支援), and from the Building Authority (Kenchiku-kyoku 建築局) with its assistance to machizukuri projects at the neighbourhood level (Murahashi 2009: 150). Finally, in March 1999, the Commission for the Advancement of Civic Engagement (Shimin katsudō suishin kentō iinkai 市民活動推進検討委員会) published its final report, in which the term 'public' (oyake 公) was defined as dealing 'with citizens and public administration'. Furthermore, the commission presented the basic guideline for cooperation between citizens and the City of Yokohama, which has been known ever since as the 'Yokohama Code"10 (Murahashi 2009: 150). By choosing Tanaka Hiroshi as the mayor of Yokohama, the three key words 'co-operation', 'decentralisation' and 'urban management' for the leadership of the administration were introduced in

10 The Yokohama Code includes six key principles regarding co-operation between citizens and government. These are: the principle of equality, the principle of respect for autonomy, the principle of autonomy/independence, the principle of mutual understanding, the principle of public accessibility and the aim of common property. To promote civic involvement, the Yokohama Code also includes three basic aspects that must be considered: the existence of a social public, the carrying out of reports and studies in order to prevent misuse of public funds, and publication of these reports and studies (Murahashi 2009: 150). 
March 2002. In December of that same year, five important strategic issues, 20 strategies, and 100 projects were summarised in a medium-term policy plan, creating a citizen-friendly city that provided plenty of opportunities for creativity and expression (Murahashi 2009: 151). Based on a major theme of this strategy plan in 2003, the machizukuri Regulation (Machizukuri jōrei まちづくり条例) was tested. Thanks to proposals from the District machizukuri Forum (Chiiki machizukuri fōramu 地域まちづくりフォーラム) and requests from the Commission of Inquiry for District machizukuri (Chiiki machizukuri kentō iinkai まちづくり検討委員会), the adoption of a regulation to promote district machizukuri (Chiiki machizukuri suishin jōrei 地域まちづくり推進条例) was finally achieved. Through this regulation numerous machizukuri projects were promoted. For example, in 2005, the City Construction Project of Yokohama (Yokohama Shimin Machibushin Jigyō 横浜町 普請事業) was introduced, which can be seen as a big step from a machizukuri for citizens to a machizukuri by citizens.

The City Construction Project is one of many offers of citizen participation from the City of Yokohama. It is a co-operative funding programme that provides for planning by citizens at the micro-level. This programme has been conducted every year since 2005. A promotional brochure called Machibushin-bun 町普請文 provides information about the procedure, the exact activities and the success of the numerous City Construction Projects. This brochure from the Department of District machizukuri (Chiiki machizukuri-ka 地域まちづくり課) is published at irregular intervals and is also available online.

Any citizen in Yokohama is able to register him- or herself for the City Construction Project as a group at the Department of District machizukuri, with a concern, a problem or a request. This is followed by an application. The application must be submitted by at least three citizens with permanent residence in Yokohama and the desired project area must be in the immediate neighbourhood, in the vicinity of the workplace, or in their own possession. The application then comes to the first contest, where the proposals are presented to a public audience and in addition are judged by a jury. ${ }^{11}$ Each group receives about four minutes to introduce their ideas and suggestions. Every group that wins the first competition receives 300,000 yen from the City of Yokohama and can start planning. With this monetary support, the groups are able to select and hire experts themselves. The plans, which are created by the experts, are then filed in the second competition, which is worth five million yen. The winning groups will then receive the money and the order for the project. Here knowledge and a great deal of energy are required on the part of citizens. The

11 The term of office for judges of the Citizen Construction Project lasts two years. The jury members consist of experts such as professors, urban planners and architects, but also of citizens selected by the mayor of Yokohama. 
administration only has the role of a co-ordinator, sets conditions, and provides assistance in the form of knowledge and capital.

The Yokohama City Construction Project is considered a very revolutionary system of citizen participation and can be counted, according to the classification by Sherry Arnstein, as a very intensive public participation method (Arnstein 1969: 220). Since the introduction of the City Construction Projects in 2009, 17 out of 20 projects have been completed. Table 1 shows that the number of applications has been greatly reduced, as has also been reported by $\mathrm{Mr}$ Horiuchi ${ }^{12}$ from the City Council (Horiuchi 2010). In 2005, 31 applications were submitted to the Office of chiiki machizukuri, but in 2009, there were only eight applications, a decrease of 74.2 percent. The number of project completions is also decreasing (YTSK 2009:19).

Table 1 Number of applications for the Citizen Construction Project

Source: YTSK $2009: 19$

\begin{tabular}{|l|l|l|l|}
\hline year & applications & $\begin{array}{l}\text { won the 1st } \\
\text { competition }\end{array}$ & project completion \\
\hline 2005 & 31 & 13 & 7 \\
\hline 2006 & 20 & 8 & 5 \\
\hline 2007 & 10 & 8 & 4 \\
\hline 2008 & 10 & 7 & $1(3$ submitted $)$ \\
\hline 2009 & 8 & 8 & - \\
\hline total: & $\mathbf{7 9}$ & $\mathbf{4 4}$ & $\mathbf{1 7}(\mathbf{2 0}$ submitted) \\
\hline
\end{tabular}

* unit in cases or projects (ken)

One main reason for this decrease is, according to Horiuchi Hiroyuki 堀内宏幸 and Minakuchi Hidehiko ${ }^{13}$ 水口英彦, the heavy demands of self-organisation. The large amount of work and of time investment in various projects scares off many potential activists, particularly if there is not a 100 percent guarantee that both competitions can be won (Horiuchi 2010, Minakuchi 2010). Since the project implementation is voluntary, citizens are involved without pay and must strive in various projects in their already sparse free time. Committed citizens groups that are excluded after the second competition may become very dissatisfied, which may reduce their willingness to participate in future projects. In 2008, the City Construction Project was used

12 Horiuchi Hiroyuki is a deputy director of the Department of chiiki machizukuri in the Department of City Organisation in Yokohama.

13 Minakuchi Hidehiko is also a deputy director of the Department of chiiki machizukuri in the Department of City Organisation in Yokohama. 
to make proposals for the upgrading of Takashima Central Park. Now I would like to introduce the project 'Takashima Central Park' more closely.

\section{The Takashima Central Park-a successful project?}

Figure 1 Photo of Takashima Central Park in summer 2012

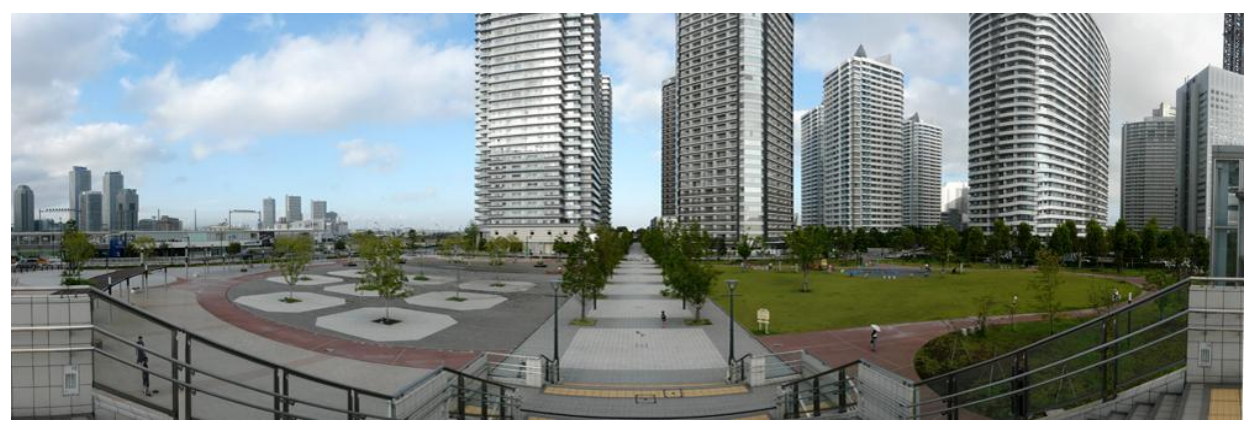

Source: Photograph by author

Takashima Central Park is located in the 51st sector in Chūo Ward 中央区, which is the area of Minato Mirai みなとみらい in Nishi District in the City of Yokohama. The park is one of the smaller parks with a total area of only 1.4 hectares. It can be reached by the subway stop Shintakashima 新高島 on the Minato Mirai Line. A self-regulatory body, the Society for Urban Development (Toshi saisei-kikō 都市再 生機構) in Yokohama manages the park (TKSK 2004: 1). The Environmental Planning Office (Kankyō sōzō-kyoku 環境創造局) is responsible for the security and maintenance of the park. The park was completed in 2007 and plays a special role as an open space in the Minato Mirai 21 area. Unlike other parks on the coast in the Waterfront Development Area of Yokohama, the park is located in the 'upcountry', without views to the sea, and was designed not only for tourists and visitors, but also mainly for the local residents. What makes the park interesting is the method of planning that was conducted with public participation (Kishida und Uzuki 2009:136). In Japanese publications, this project is described as a very successful machizukuri project.

The Takashima Central Park Project is considered to have two main phases. The first phase of the project began in 2003 with the drafting of the basic concept of the park. Citizens were recruited and invited to participate in workshops to share their opinions. Each of the three citizen groups ${ }^{14}$ of the workshops developed a draft plan for the park, which was subsequently taken and analysed by the administration. 
Based on these ideas and opinions, a draft plan was prepared in the same year by the Urban Development Corporation. ${ }^{15}$ The police and the Office of Greening suggested changes for security reasons and lack of financial resources. The City government, however, made no provision for citizen participation for this phase. Citizens were therefore not informed of the changes because at the time the decision was made, the process of participation was already completed. The actual implementation of the first phase of the project was completed in 2005 and the official grand opening of the park took place on July 25, 2007 (YTSK 2007).

The second phase of the project began in 2008 and was completed in 2010. It was initiated by residents living nearby because of the existing design defects of the park. This phase is called the 'Family Garden in Takashima Central Park' Takashima chūō kōen famirii gāden 高島中央公園ファミリー・ガーデン. The local residents accepted the offer of the City of Yokohama and volunteered at the City Construction Project to implement ideas for a more beautiful design of the park. The elements which were initially cut because of safety issues and financial viability by the police and the Environmental Planning Office in 2003, became the reason why the citizen group 'Takashima Central Park Gardening Club' Takashima chūō kōen gādeningu kurabu 高島中央公園・ガーデニング・クラブ signed up for the City Construction Project in 2008. The joint development of concepts within the group of citizens has contributed towards the building of one community. The proposals and plans of this group were implemented in 2009. Since 2010, various events have taken place. It is not inherently easy to answer the question to what extent the whole project was successful or not.

As a general rule, a citizens' participation process does not necessarily guarantee success, because a meaningful and effective method must be considered case by case for the specific project (Reinert 2003: 38). In evaluating the effectiveness of political action, the question is always about the extent to which the objectives were reached. A method is effective when a relatively high yield is achieved at low cost (Geißel 2008: 35). A project in open space planning is effective when the problem is solved or the task has been fulfilled. However, problems are usually complex, so clear effectiveness is not easy to detect. Many evaluations are not based on objective performance criteria and data, but on beliefs and impressions (Geißel 2008: 38). At the beginning of each participating process questions on the desired objectives should be asked (Vetter 2008: 17).

The hierarchy of criteria can always be taken differently, depending on the backgrounds of democratic theory. Is a project truly successful when one population

15 The Society for Urban Development (Toshi kiban seibi kōdan 都市基盤整備公団) was abolished in July 2004 and re-established under the name Toshi saisei kikō 都市再生機構 (TKSK 2003). The corporation is an independent administrative institution (dokuritsu gyōsei hōjin 独立行政法人) whose members are composed of state officials (kokka kōmuin 国家公務員) according to the law (E-GOV 2010). 
group is excluded from the decision-making process? Is success related to the number of participants? Is the project successful if it was carried out efficiently and a solution with minimum time and working costs was found? The measure of success is therefore very difficult to perceive because success depends on the objectives, on the weightings of success criteria, and on the different actors (Geißel 2008: 41). Nevertheless, some factors in the success of public participation process are important and detectable from various scientific studies (Vetter 2008: 18). In this context, Vogt shows three aspects as a prerequisite for effective participation: the participants (individuals or groups), the organisers of citizen participation (institution or government), and the common interface of the two actors (Vogt 2001: 38). In addition to the actors and their relationships, the right time, the task, and the quality of participation are important for the success of a participation project (Vetter 2008: 1819).

The analyses and tests of the extent to which the participation processes in the Takashima Central Park Project were successful or not and the possible causes and reasons will now be explained according to the two project phases.

\section{Project Phase 1 (2003-2007)— the basic concept of the park}

The aim of this project phase was to develop the basic concepts and basic plans for the park with the help of citizen participation. To address the opinions and ideas of citizens and incorporate them into the planning of the park was deemed very important by the administration. The competent administrative departments for the construction of the park were the Department for the Promotion of Minato Mirai 21 of the Town Planning Office in the City of Yokohama (Yokohama-shi toshi keikakukyoku Minato Mirai 21 suishin-bu 横浜市都市計画局みなとみらい 21 推進部), the Administrative Centre of the Society for Urban Development (Toshi kiban seibi kōdan Yokohama chūō toshi seibi jimusho 都市基盤整備横断横浜中央都市整備 事務所) and the Division of Park Planning in the Office of Greening (Yokohama-shi ryokusei-kyoku kōen-bu keikaku-ka 横浜市緑政局公園部計画課). The Yokohama Minato Mirai 21 Joint-stock Company (Kabushiki gaisha Yokohama Minato Mirai 21 株式会社横浜みなとみらい2 1) and the Research Institute for Civil Design (Kabushiki gaisha shibikku dezain kenkyū-jo 株式会社シビックデザイン研究所) were designated to manage the task of citizen participation (TKSK 2004: 1).

In accordance with article 56 of the legislation of the Town Planning Act of 1968, citizen participation in the form of a public hearing or public inquiry of local residents was required (E-GOV 2010). The administration of the City of Yokohama however, decided to apply a more intensive participation method. Instead of a public hearing, workshops were held and advertising brochures recruited citizens from the City of Yokohama. Conducting the public participation through discussion and 
workshops is certainly a good way to collect the different opinions. The workshop supports the acquisition of these different opinions and views, especially if in addition to citizens, experts and city officials are involved. In addition, the process of interaction and co-operative partnership can be well represented through discussions and workshops. With each participant being entitled to express views and ideas without obligation, the city council has chosen a very supportive form of cooperative participation. Through the co-operation of different participants such as representatives from the public, businesses, and individuals from the city council, this process promoted the so-called bridging of social capital. ${ }^{16}$

As the park was located in an area that was still uninhabited in 2003, every citizen of Yokohama who was interested could participate. On the one hand, this was very laudable, but on the other hand, it was problematic, as the citizens had little or no relationship to the park and the surrounding area, because they were not local residents (jümin 住民). In total, 51 interested citizens from various parts of Yokohama signed up to participate for the basic concept of the park. Through a random draw, the number of participants was finally set and reduced to 21 (11 women and ten men), as it had been decided beforehand that seven citizens in three separate groups would be involved. The draw was made at random to obtain a thoroughly mixed membership structure and to prevent the formation of already known active core groups. This method of selection by lot was carried out in the so-called planning cell, which is widely used in German-speaking countries (Langer and Oppermann 2003: 301). In Groups A and C, 4 women and 3 men participated and in Group B, 3 women and 4 men. The groups were sorted fairly evenly by gender. Limits on timing and content were organised by a co-ordinator of the Research Institute for Civil Design. During the relevant discussions, a moderator from the same research institute tried to create a comfortable climate for discussions in each group. In this case, the co-ordinator and the three moderators were external impartial mediators of the Research Institute for Civil Design, which was important for successful participation, according to Langer and Oppermann (2003: 301). By dividing into three smaller groups, the co-ordinator enabled a smoother exchange of views. The respective moderators forced debate and mediated in crises and conflicts.

16 Social capital can be divided into binding and bridging social capital. Binding social capital is available in already existing contacts within a group, whereas bridging social capital is available in co-operation among different unknown population groups. Bridging social capital plays an important democracy-promoting role (Geißel 2008: 40). 
Figure 2 Site inspection by all participants

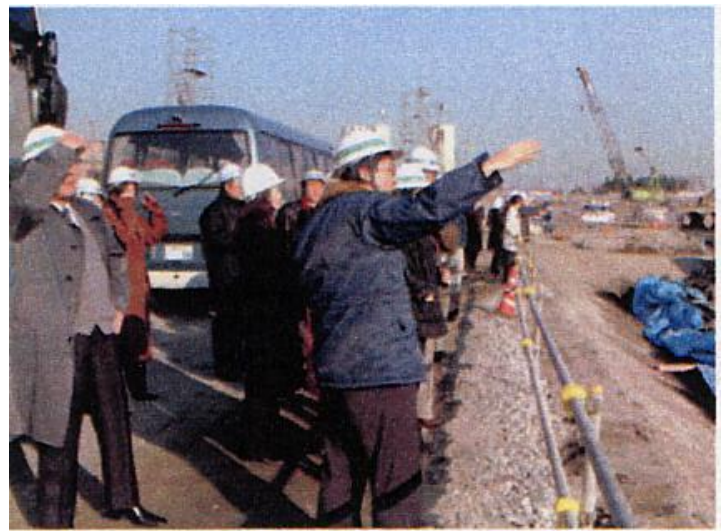

Source: TKSK 2004: sankō 16

Figure 3 In the foreground are the three discussion groups and in the background the representatives of the administration

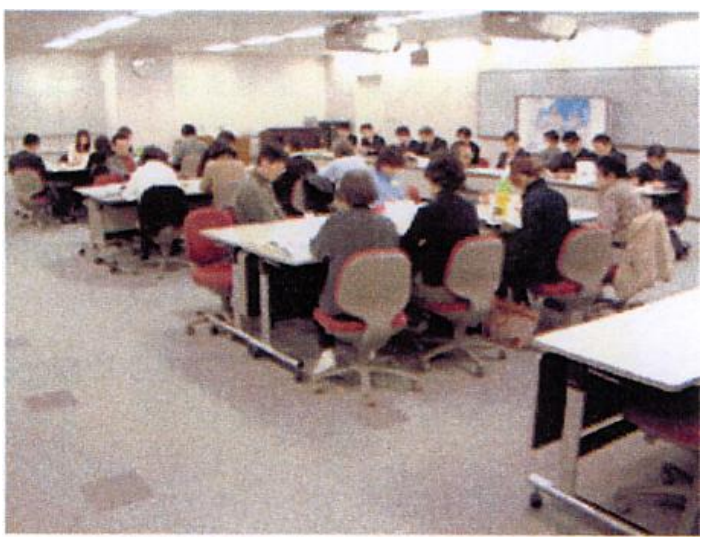

Source: TKSK 2004: sankō 17

Both Mrs Shimizu ${ }^{17}$ 清水 from Group A and Mrs Amamiya ${ }^{18}$ 天宮 from Group B were very satisfied with the work of the moderators and felt they had proved their competence.

17 Mrs Shimizu took part in the workshops as a citizen and the statement is taken from a field report. Age and occupation are unknown.

18 Mrs Amamiya also took part in the workshops as a citizen and the statement is taken from a field report. Age and occupation are unknown. 
The representatives of the citizens were invited to five workshops to express their opinions, needs and ideas from January to June 2003 through discussions and conferences (kondankai 懇談会). The results of these workshops were three draft plans (see Figures 4-6) from each citizens group, where their needs and wishes were implemented. These five discussions were held on a Friday on the following dates in 2003: January 31, February 28, March 28, May 9 and June 20. This period of about five months for the discussions was relatively straightforward, because according to Vetter, a citizen participation process needs to be predictable in time and show an official final result. The intervals of about four weeks between dates were well chosen. The specific choice of dates has to be evaluated negatively, because according to Seko the date should always be chosen so that as many citizens as possible can participate (Seko 2009: 38). However, since all five workshops were held on a Friday during the day, this could have potentially posed a problem for employed persons. The poor presence of the participants can perhaps be attributed to this aspect. Looking at each workshop day, in the first workshop 70 percent of the participants were present, in the second and third workshop 80 percent, in the fourth workshop 60 percent, and in the final workshop 80 percent. Of the total 35 days of presence, Group A had 22, Group B 24, and Group C 29 days of presence, resulting in a 70 percent average attendance rate of participants.

Mrs Amamiya noted that during the group discussions, participants who appeared more confident, talkative and extroverted, had an advantage. This aspect was also criticised by Nishikawa Yoshiaki 西川芳昭 and he therefore called for a competent moderator. According to Mrs Amamiya, the co-operation with representatives of the administration and the organisers was very good and she mentioned that through the citizen participation, her impression of the administration had changed positively. Mrs Shimizu agreed and added that through participation in the project identification with her city had intensified. However, they complained about the lack of feedback from the City Council on the citizens' proposals. It is precisely this resonance that is important for further engagement by citizens. The final feedback to the citizens' commitment was provided only with the official opening of the park in 2007, where all participants were invited to see the final result. 
Figure 4 Draft plan of group A

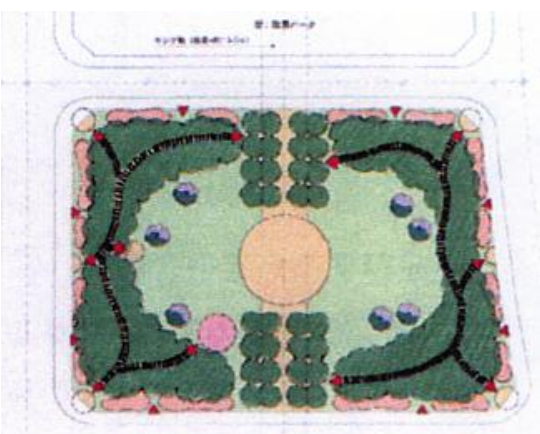

Source: TKSK 2004: sankō 32

Figure 5 Draft plan of group B

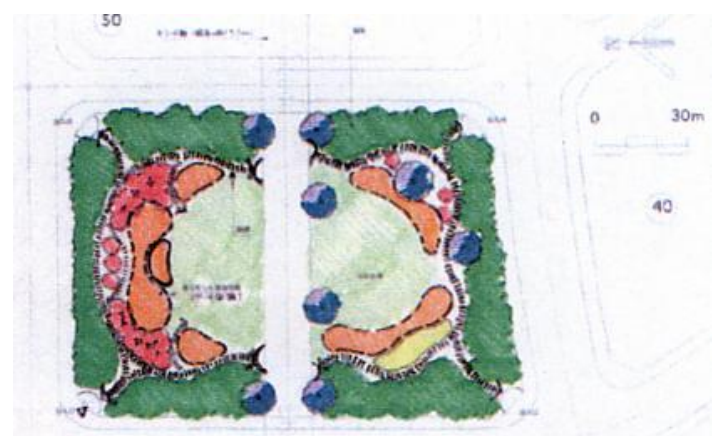

Source: TKSK 2004: sankō 32

Figure 6 Draft plan of group C

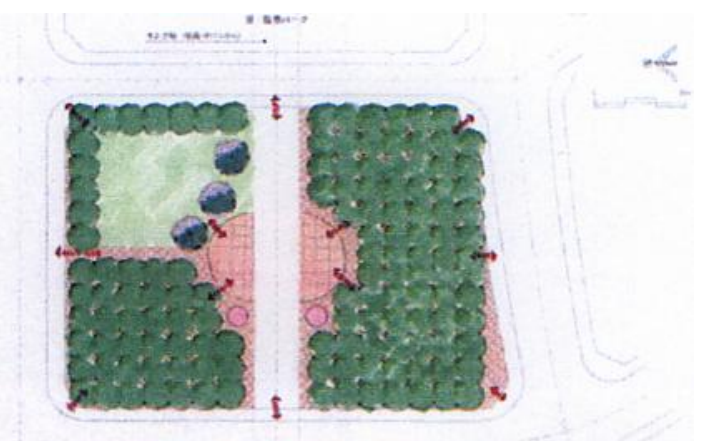

Source: TKSK 2004: sankō 33 
Figure 7 Draft plan of the Society for Urban Development after combining the three draft plans of the discussion groups held in 2003/2004

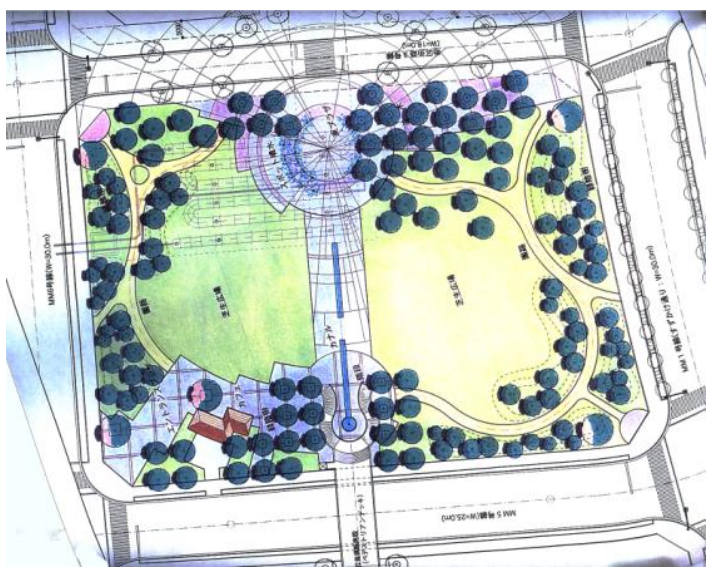

Source: TKSK 2004: 12

Figure 8 Draft plan of the Society for Urban Development after the review by the police and Environmental Planning Office in 2005/2006

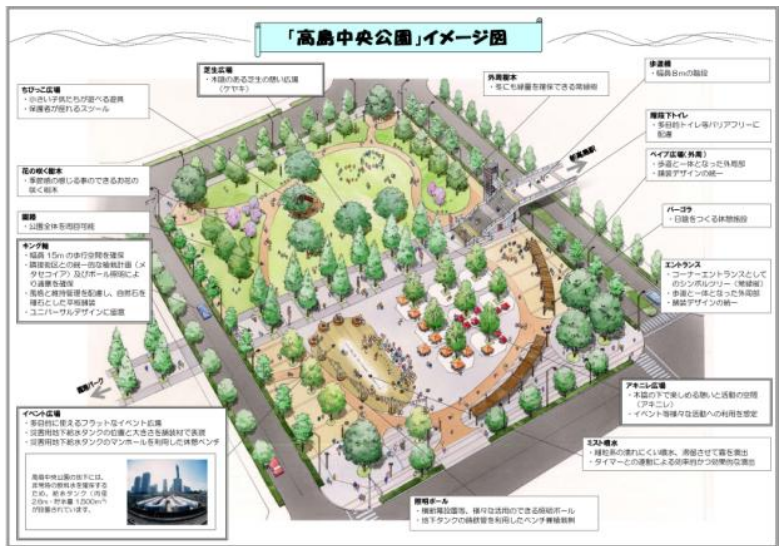

Source: YTSK 2010c

The participation process was relatively successful except for minor defects. Both the competence of the participants and the choice of an intensive participatory method gave the impression of a successful project. Looking further at the progress of the project, particularly the implementation phase, which was driven exclusively by the city council, we recognise some negative points. A lack of internal co- 
operation between the city government offices and departments, because of a certain vertical fragmentation of management (tatewari gyōsei 縦割り行政), led to the basic park design being changed. According to Tsukada Yōichirō 塚田洋 from the Department for the Promotion of Minato Mirai 21, the concepts and preliminary designs of the citizens were collected by the Town Planning Office and sent to the Society for Urban Renewal for the purpose of designing the details. Subsequently many offices, such as the Environmental Planning Office, responsible for the parks and the police, responsible for security and safety were asked for their opinions. According to Mr Tsukada, the shape of the park changed slightly (Tsukada 2010), while Mr Sakai Kazuhiro 坂井和洋 from the Environmental Planning Office talked about major changes. The main reasons for the changes to the plan were the security and financial aspects. The police, for example, criticised visual disabilities or the emergence of so-called 'dark corners' due to excessive plantings; the number of plants was therefore radically reduced. The financial aspect led to the disappearance of the cafés and benches and to other changes to allow for easier maintenance and management of the park. The citizens were not informed of the proposed changes. And in the end only the administration decided which aspects should be changed or reduced (Sakai 2010).

$\mathrm{Mr}$ Tsukada reported that some participants were disappointed about the changes and reductions of ideas without consultation with the citizens who had participated in the planning. The design plans for the park were not shared and discussed by all participating departments and agencies, but only passed from one department to another, so partnership co-operation within the city government was limited (Tsukada 2010). According to Uta Hohn, for sustainable urban development networked planning and action are essential (Hohn 2000: 532). The primary objective was simply to poll the opinions of citizens in order to make further plans for the park. $\mathrm{Mr}$ Tsukada said: "We only ask for the opinion of the citizens, take this as a basis and then run the project through. ...Although we take responsibility for the opinions of the citizens, the project will again return to the City of Yokohama and the Office of Urban Renewal' (Tsukada 2010). The participants were used as inexpensive bringers of ideas, who no longer were involved in the project. A long-term form of participation from the planning phase to the decision phase to the implementation of the project was not on the list of the administration's objectives. The specification by the former city council to canvass only the opinions of citizens is now criticised even by Mr Sakai. In his opinion, citizens should take responsibility for their own opinions and suggestions for what can be achieved only if continuous participation takes place (Sakai 2010).

In summary, the participatory process of the first project phase in 2003 was successful in itself, but the further course of action was marked by failure. The lack of involvement of citizens in the later project processes and the late co-operation with the police to examine safety issues are major points of criticism and they can be 
considered as failures. Because changes were made without consultation with the citizens, the planned park had very little to do with the actual park that was built. The late involvement of the police is also criticised by Mr Tsukada and he deplores the changes brought about by the strong objections from the police. Collaboration with the police during the planning phase would be highly desirable but according to Mr Tsukada in reality is quite difficult. It can be argued that citizens' participation in an emerging field is only meaningful if the participants are actually living there, in the sense of being local residents (Tsukada 2010); only then continuity and a citizen's commitment even after project completion can be guaranteed. Mrs Uchida, ${ }^{19}$ a resident of the MM Towers next to the Takashima Central Park, commented that it would have been better if the development of the basic concept of the park had been carried out with local residents. According to her testimony, she would have loved to participate in it. However, when she moved to the new site, the park had already been completed (Uchida 2010). The fact that citizens from various districts of Yokohama were involved in planning for the unknown future residents meant that the actual users and local residents had little say in what was required for their everyday needs.

\section{Project Phase 2 (2008-2010) - Family Garden in Takashima Central Park}

Mrs Naitō Noriko 内藤能里子 works as a landscape architect, focusing on park planning. As she appreciates very much the attitude of the City of Yokohama, she wanted to contribute to park planning. She and three colleagues searched for a suitable location and drew the attention of citizens by advertising the City Construction Project of the City of Yokohama. Coincidentally, a female friend of a colleague lived next to Takashima Central Park. This friend along with two other mothers joined together because of specific defects and deficiencies in the planning in Takashima Central Park. The deficiencies of the park were only realised through everyday use. Too little green space, barely adequate seating, inadequate children's playground equipment, too few shady spots, et cetera, had led to limitations in the everyday use of the park. These deficiencies were caused by transformations and changes made by the City Council and the police in the first project phase in the years 2003 and 2004 without further consultation with the citizens. Mrs Naitō therefore tried to support these three dedicated mothers by joining together with them and signed up for the City Construction Project in 2008. This led to the founding of the 'Takashima Central Park Gardening Club'. The aim of the Gardening Club was to overcome these deficiencies through creative means and measures (Naitō 2010).

19 The name was changed at the request of the interviewees in order to ensure anonymity. 
Between January 7 and March 28, 2008, individual citizen groups could sign up for the Yokohama City Construction Project. After registration, each group received support from the city, and a co-ordinator, who assisted in process, content and discussions, was provided free of charge. The concrete proposals and plans from these initial discussions had to be submitted between April 21 and May 23, 2008 for the first contest. In this phase, groups without registration were also able to submit their plans and proposals. In total, 15 citizen groups were registered for the City Construction Project 2008, ten of which competed for the first competition. The choice of participants was not determined by the administration, but by the citizens themselves at the urban micro-level.

Figure 9 Presentation of the individual citizen groups to the jury and the audience in Yokohama in 2008

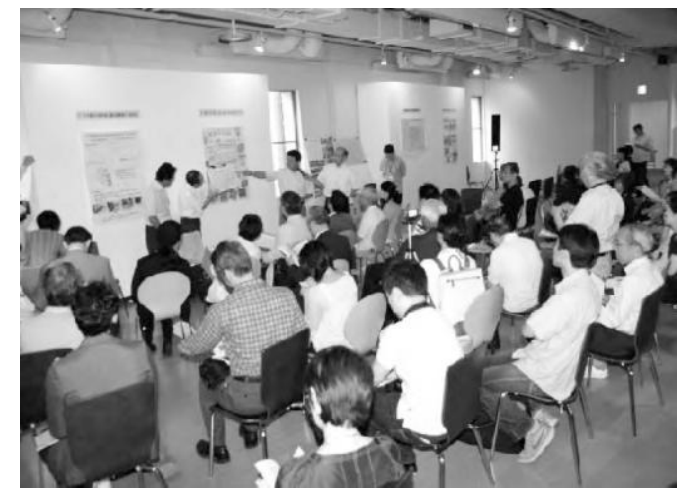

Source: YSKSC 2008

Figure 10 Group discussion of the Taskahima Central Park Gardening Club

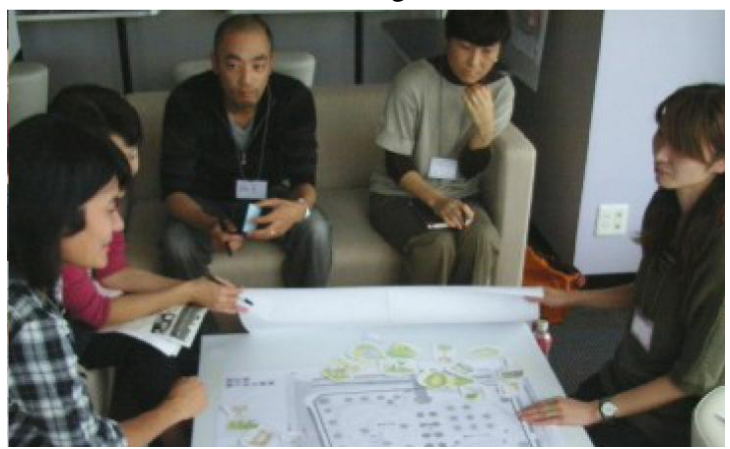

Source: Personal photograph taken by a participating group member, 2008 
All groups, including the citizens group 'Takashima Central Park Gardening Club', had different issues and proposals for their personal project area in Yokohama. The plan was created according to the conditions prescribed for the City Construction Project for any group of citizens. Among these conditions was one that each citizen group had to recruit three additional citizens. The recruiting of citizens to join a group was, according to Mrs Naitō, very difficult because not many were willing to invest so much time and work in the project. To bring awareness to as many people as possible, the Takashima Central Park Gardening Club distributed information flyers (chirashi 散らし) in the area (Naitō 2010). This informal and unrestricted selection of participants from the 'bottom' by recruiting interested citizens by flyers and advertising brochures is a very appropriate method, but only for projects on a smaller scale. After a long and laborious advertising campaign, some interested citizens signed up and the Takashima Central Park Gardening Club was founded. The first proposals and ideas of the group were presented in the first competition held on June 22, 2008 (see Figure 9). A jury consisting of professors, members of research institutes, board members of a NPO organisation as well as citizens, assessed the projects in both the first and the second competition. The diverse composition of the jury is very positive. The regular change in the jury at two years' intervals also provides more objectivity. The jury evaluated the projects in five categories, such as 'originality', 'feasibility', 'public impact', 'efficiency' and 'development potential within the chiiki machizukuri' (YSKSC 2009). Seven out of the groups won the first contest and received the prize of 300,000 yen capital assistance for further work and preparations for the second competition (YTSK 2010b). The city then provided representatives of the Environment Planning Office for each of the seven groups, who were available to answer questions, to check safety and security aspects, and to examine the feasibility of proposals.

The Takashima Central Park Gardening Club also won the first contest and then began to initiate concrete measures and ways of working. To seek the views of a large number of stakeholders and residents, the group began to apply intensive participatory methods. Just as in the first project phase, where the basic design of the park was developed in 2003, workshops were held over the weekend in the immediate vicinity of the park and the participants were divided into three groups, to exchange opinions about the pros and cons of the park. The time span of these workshops was well arranged for citizens. Although the objective of these workshops was simply to poll the opinions of citizens, a sense of continuity was ensured as all interested and committed people could continue working for the project. Mr Matsumoto, for example, accepted the offer and he drove the project forward very actively. Today he is the representative of the Takashima Central Park Gardening Club, which 
has become an aigokai ${ }^{20}$ 愛護会 in 2010. The number of participants in the workshops decreased from 17 to 10 people but nevertheless, they were very motivated (Matsumoto 2010). Mr Sakai of the Environmental Planning Office of the City of Yokohama said: 'The Gardening Club was a very committed group of people who looked for longer-term solutions' (Sakai 2010). Because participation was voluntary, it was mainly taken up by interested or concerned local residents in the sense of jümin and persons who identified with the object or the discipline. The co-operation among the citizens was, according to Mrs Naitō and Mr Matsumoto, promoted heavily by the co-ordinator of the Research Institute for Civil Design, proving his competence. The results of the previous meetings were compiled and again discussed. After completing the workshops, the participating group was disbanded and only the most committed participants, like Mrs Naitō and Mr Matsumoto, drove the project forward.

After the workshops, a survey was initiated. To increase the range and to seek more opinions, 3,500 survey forms were distributed to all residents within the block of flats. The response rate was estimated at about 20 percent by Mrs Naitō, with approximately 700 survey forms being returned. The poll showed a need for more shade, flowers, trees, sand boxes, playground equipment, and more seating facilities (Naitō 2010, Matsumoto 2010). Within the City Construction Project Yokohama, the citizens group Takashima Central Park Gardening Club used both passive and active participation methods. All data collected from the three workshops and the survey went into the draft plan (see Figure 11) for the second competition. In this case, the draft plan and the planning contribution were very professional, since $\mathrm{Mr}$ Matsumoto as an architect and Mrs Naitō as a landscape architect pushed the citizen group and the project forward. This allowed the group to save on other experts in the field of planning and architecture. Citizens without any planning expertise have little chance of succeeding with their ideas without any expert help. In addition to design elements, they introduced their own community group as the Takashima Central Park Gardening Club and their engagement in such activities as the monthly cleaning and garbage collection campaign (YSKSC 2009). This support of the community in a newly built residential area with no chōnaikai or jichikai was for the jury, especially for Mr Kinoshita Isamu 木下勇, a professor at Chiba University working in the field of environmental design, very essential.

20 Aigokai or kōen-aigokai is the name of an association within a chōnaikai that looks after the care and maintenance of local parks (YKSK 2010). 
Figure 11 Draft plan of the Takashima Central Park Gardening Club for the second contest

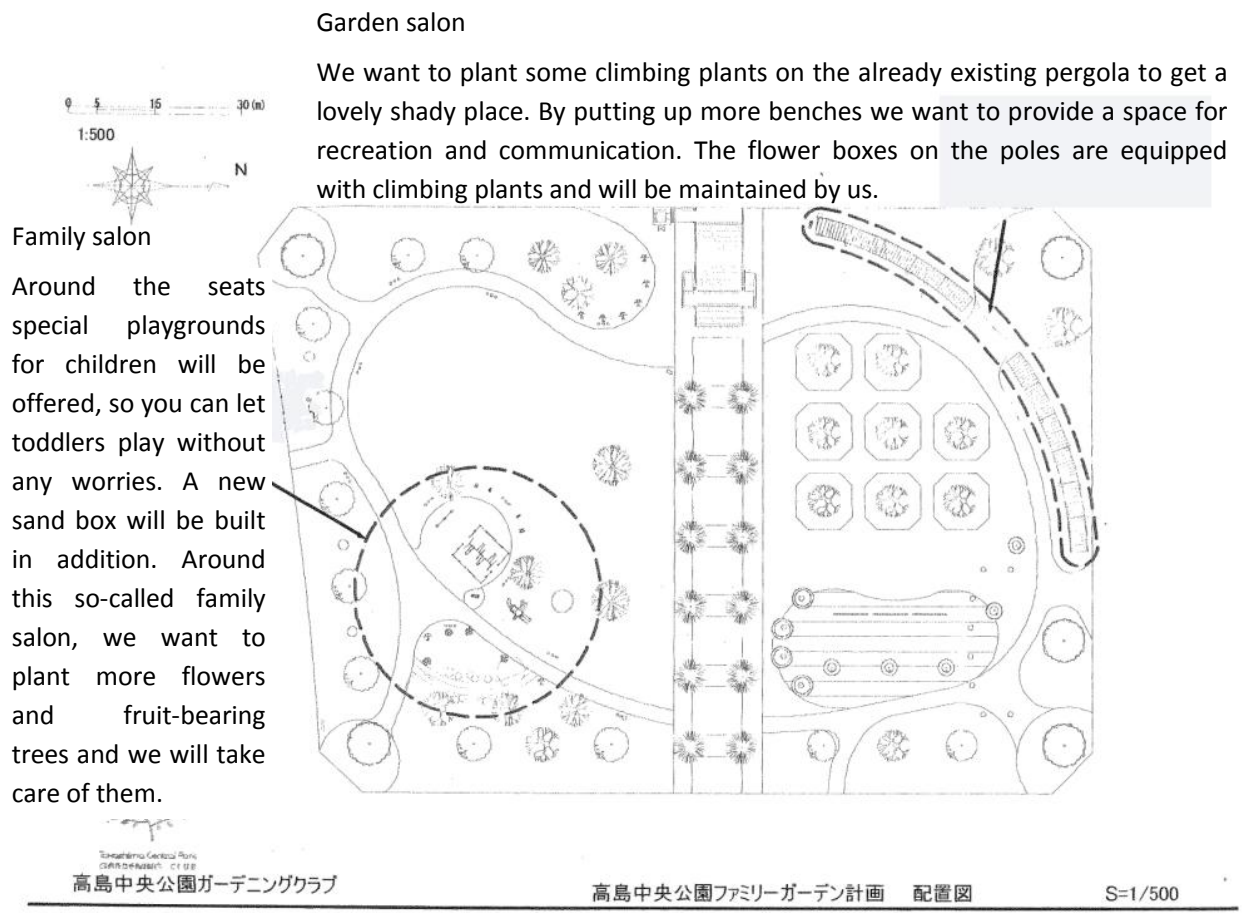

Source: TCKGC 2008

After the Takashima Central Park Gardening Club won the second competition and received five million yen, they implemented the plans in 2009 through the members of the Gardening Club and with the help of local residents. Experts in architecture and construction supervised the construction works. Shrub and herb plantings, construction of a walkway, tree plantings, construction of a sand pit, and installation of benches were among the main works implemented (see Figure 11). According to $\mathrm{Mr}$ Matsumoto, today, 2010, there are nearly 20 members in the Takashima Central Park Gardening Club and the club was officially appointed as an aigokai for the park in July 2010. The co-operation between citizens and city officials has had positive effects for both sides. Mr Matsumoto and Mrs Naitō, for example, thought that it was very reassuring to see management representatives in person, because that way they knew who was working for the citizens in the administration. Before implementing the project, Mrs Naitō and Mr Matsumoto had had a very rigid and conservative impression of management and administrative staff because they always strongly criticised the initial proposals. After lengthy discussions and multiple meet- 
ings, however, the image of the 'dusty management' changed into that of an 'administration that advocates for citizens' said Mr Matsumoto (Matsumoto 2010). Due to the good partnership with members of the administration, the image and reputation of the City of Yokohama improved. By co-operating with the administration, citizens could understand the motives for critical comments by the management and many began to raise their understanding. Thus, all respondents could imagine future co-operation with the City Council in Yokohama. Mr Sakai, representing the city administration, was also very pleased to learn about the opinions of citizens and was surprised by the commitment of the participants (Sakai 2010).

The City Construction Project requires participation by citizens in advance of the official notification to the City Council and the actual planning phase. It boasts an interesting approach where the projects are not driven with, but by citizens. This method facilitates the forming of a community by participation at a very early stage, of which the Takashima Central Park Project offers a clear example. Since the task of the authorities is merely the creation of conditions and the provision of capital or knowledge, intensive citizen participation can be seen throughout the project. According to Nishikawa's issue of 'continuity', the City Construction Project offers a very good basis for a successful public participation process. The total duration of the project of two years and three months from January 7, 2008 to late March 2010 was prescribed by the City Council. This relatively long time span of two years can appear negative to citizens, but through many intermediate goals and milestones such as the two competitions, the project period was manageable. Thus, this model can be seen to be relatively unique. Nevertheless, there are similar methods with civil competitions and capital grants in the City of Fukuyama 福山市 in Hiroshima Prefecture 広島県, or in the Setagaya District 世田谷区 of Tōkyō Prefecture.

Figure 12 Construction of a walkway by residents and members of the Central Park Gardening Club Takashima

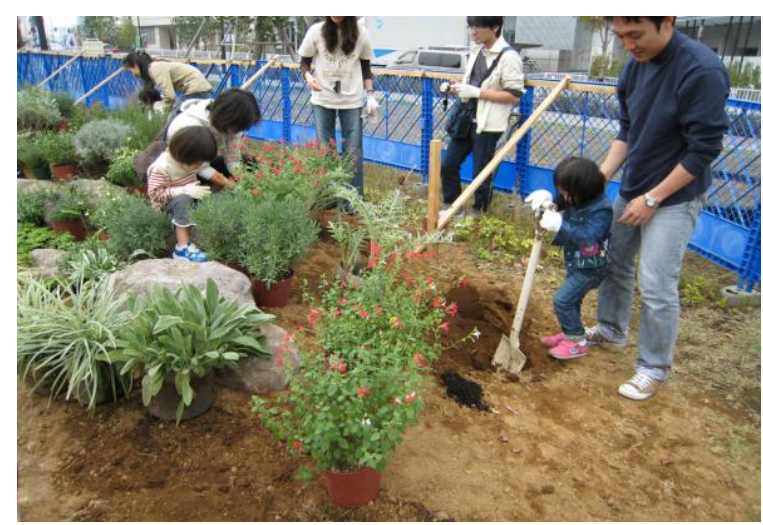

Source: Gardening Club 2009 
Figure 13 Plantings by residents and members of the Central Park Gardening Club Takashima

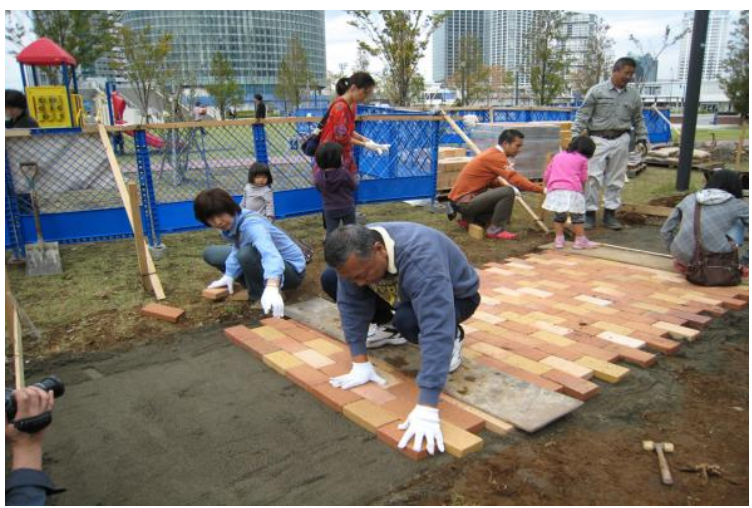

Source: Gardening Club 2009

The autonomy of the citizens was strongly promoted through self-organisation and self-determination regarding methods or the selection of experts. This increased autonomy was also coupled with a higher incidence of expenditure for the citizens themselves, whereas the tasks were kept low for the city council. We must not forget that any participation is associated with a takeover of duties, responsibilities and obligations. Hohn has noted that ' $[\mathrm{m}]$ ore rights means at the same time - and this is often overlooked - more responsibility and more duties, but the willingness to take responsibility is often missing' (2000: 532). Mr Sakai from the Environmental Planning Office, responsible for parks in Yokohama, emphasised the importance of the concept of responsibility and expressed the wish that people should reflect on the consequences of their opinions and take feasibility and usefulness into account (Sakai 2010). This opinion is obvious because in the case of damage or injuries in the parks, the Environmental Planning Authority has to take responsibility. The importance of responsibility was clear from the start for the citizens group of Takashima Central Park Gardening Club. Therefore, Mr Sakai praised this citizens' group and hoped for similar responsibility in future citizens' projects (Sakai 2010). According to Mrs Ōkage Naoko, ${ }^{21}$ the City Construction Project was initiated to increase the autonomy and self-determination of citizens, in keeping with the Yokohama Code. Citizens become key players and are on a par with the administration. The administration hopes that the City Construction Project will help to increase the autonomy of citizens, promote the formation of a community, get new ideas or innovative proposals, and enhance civic engagement (Ōkage 2010). However, Mr Horiuchi sug-

21 Mrs Ōkage Naoko is also a deputy director of the Department of chiiki machizukuri in the Department of City Organisation in Yokohama. 
gested in an interview that there are additional monetary reasons for participation. According to his testimony, the submission of planning expertise to the citizens is a significant saving and reduction in capital for the city administration. Not only planning and implementation but also maintenance and care are taken in hand by the citizens, which is very economical for the administration through a payment of 5.3 million yen (Horiuchi 2010).

From the perspective of the Department of chiiki machizukuri, which initiated the City Construction Project, the 'Family Garden in Takashima Central Park' project was a complete success because the formation of a community cannot be handed down or arranged by the City Council but it can be promoted by it. The project was successful also for the citizens' group because it was possible to achieve all deadlines and goals, even those intended from the project in 2003. Paradoxically, success was based on the partial failure in the first project phase in 2003 and the resulting dissatisfaction of the residents. In summary, the participatory process of the second project phase in 2008 was a great success.

\section{The way to successful citizen's participation}

The choice of the participation method depends on the project itself and on the objectives. Not every method is suitable for achieving the latter (Vetter 2008: 20). However there are some aspects that are important for any kind of project or objective. For example, the timing of participation, according to Nishikawa, is of great importance. Citizens' participation in the final phase, when decisions have already been made, is no participation in the sense of open space planning. The involvement of citizens in the earliest stages of planning is of far greater relevance, which can be seen in both project phases of the Takashima Central Park Project. Continuity (keizokusei 継続性) is also very important for a successful participation process, where citizens are involved not only in the initial phase but also throughout the completion of the project until the construction phase (Nishikawa 2007: 98). In the second project phase in 2008, continuity was a given, whereas in the first phase in 2003 it was not. A participatory process should not be regarded as a short-term event in the sense of a project (jigyō 事業), but rather as a long-term movement (undo 運 動) (Satō 2007: 32). Projects or problems should be solved in a limited period of time so the end can be foreseeable for citizens. However, the time span is also influenced by the quantity of participants. For example, when involving as many people as possible in a decision process, it is better to offer a simple and less timeconsuming method (Vetter 2008: 19-20), as can be seen in the development of the basic concept of the park in 2003. 
Regarding the characteristics of the citizens involved, apart from personal factors, understanding of democracy, individual concern, motivation and communication skills are significant (Vogt 2001: 38-39). This includes a high degree of sensitivity and awareness of moral and political tolerance, no fear, a critical stance towards authority, and stable self-esteem (Lehnen 1980: 35). Even people with a moderate ability in democracy can, through participation, improve their democratic skills by focusing on problem-specific knowledge. Through discussions and information, relationships can be better understood, thus expanding political, intellectual and cognitive horizons (Geißel 2008: 38). The resources of the participating individuals, particularly their level of education or their interest in political issues, also play a significant role (Vetter 2008: 18). In order to develop political commitment and responsibility for others, a participant should be affected in some way by the problem or the object. Furthermore, he or she must identify with the city, to show willingness to participate (Mehlhorn 1988: 11). The degree of success regarding participants is thus very difficult to measure. Often the representatives of the administration count the number of participants as a measure of success. According to Satō, it is not the number of participants that is relevant, but the number of participants who are still involved in the project after official participation (2003: 1-7). The attitudes and behaviour of the administration are also important factors that can be responsible for success in the participation processes. The administration can raise motivation and, therefore, have an important mobilising function. However, the administration can also be de-motivating and consequently contribute to the failure of the participation process (Vetter 2008: 18-19). The continuity of competent administrative staff is important to ensure long-term co-operation with concerned citizens. Unfortunately, it happens that the original set of representatives managing the public participation process undergoes change. This personnel restructuring is called jinji idō 人事異動 in Japan. As a result, citizens lose confidence in the administration, because newly recruited employees often do not know much about the former public participation process, as could be seen in the first as well as in the second project phase.

Participation will only be successful when co-operation takes place between the actors (Vogt 2001: 41). Co-operation within the various departments is also of great relevance, as demonstrated by the first project phase from 2003 to 2007. Regarding co-operation with citizens, a user-friendly and citizen-friendly way, presenting a 'soft surface' (sofuto men ソフト面) should be chosen (Kuniyoshi 1989: 249). Not a single player should win at the expense of other participants, but all players should receive additional benefits, as shown in the second project phase in 2008. A partnership relation between citizens and administration should be preferred, because the administration has to be understood as representative of the concerned citizens (Vogt 2001: 40-41). A process incorporating collaborative and consensus-oriented communication enhances the bridging of social capital that plays an important role in 
promoting democracy. The strengthening of both bridging, and binding social capital is important as a criterion of success for a public participation process (Feindt 2008: 40), as shown in the second phase of the Takashima Central Park Project. 


\section{REFERENCES}

Arnstein, Sherry. “A Ladder of Citizen Participation.” In JAIP (Journal of the American Institute of Planners), 35/4, July 1969, pp. 216-224

E-GOV. "Gyōsei tetsuzuki-hō" 行政手続法 [Administrative Procedure Law]. 2010, http://law.egov.go.jp/htmldata/H05/H05HO088.html, accessed September 2010

Feindt, Peter, et al. "Strukturbildungsprobleme in lokalen und regionalen Agenda-Prozessen." In Lokale ,Agenda 21'-Prozesse, Reihe "Städte und Regionen in Europa", 7, edited by Hubert Heinelt and Eberhard Mühlich. Opladen: Leske und Budrich, 2008, pp. 217-240

Flüchter, Winfried. Stadtplanung in Japan. Problemhintergrund, gegenwärtiger Stand, kritische Bewertung. Mitteilungen des Institutes für Asienkunde Hamburg, 97. Hamburg: Verbund Stiftung Deutsches Übersee-Institut, 1978

Geißel, Brigitte. "Wozu Demokratisierung der Demokratie? Kriterien zur Bewertung partizipativer Arrangements." In Erfolgsbedingungen lokaler Bürgerbeteiligung, edited by Angelika Vetter. Wiesbaden: Verlag für Sozialwissenschaften/GWV Fachverlag, 2008

Geocities. "Shichō e no tegami” 市長への手紙 [Letters to the Mayor]. 2010, http://www.geocities.jp/picaly1/31history/1960.html, accessed September 2010

Harada, Naohiko 原田尚彦. “Shi-chō-son.” 市町村 [Municipalities]. In Dai Nihon Hyakka Jiten 大日本百科事典 [Encyclopedia Japonica], vol. 8, edited by Ōga Tetsuo 相賀徹夫. Tōkyō: Shōgakukan, 1972, p. 566 [1st edition 1969]

Hohn, Uta. Stadtplanung in Japan. Geschichte - Recht - Praxis - Theorie. Dortmund: Vertrieb für Bau- und Planungsliteratur, 2000

Ishida, Yorifusa 石田頼房. Nihon kindai toshi-keikaku no hyakunen 日本近代都市計画の百年 [100 Years of Modern City Planning in Japan]. Tōkyō: Jichitai kenkyū sha, 1987

Kishida, Hiroshi 岸田比呂志 and Uzuki Morio 卯月盛夫. Toshizukuri senryaku to purojekuto manejimento. Yokohama minatomirai 21 no chōsen 都市づくり戦略とプロジェクト・マネ ジメント。横浜みなとみらい21の挑戦 [Strategy and Project Management for Urban Planning. The Minatomirai 21 Challenge]. Kyōto: Gakugei, 2009

Kozawa, Akira コザワアキラ and Akimoto Yasuyuki アキモトヤスユキ. "Jichitai to 'sanka no machizukuri”” 自治体と「参加のまちづくり」. 横浜のパートナシップの町づくり [SelfGoverned Corporate Body and Participation in Urban Planning. Participation in Yokohama Based on Partnership]. Zōkei, No. 9,6., 1997, pp. 88-93

Kuniyoshi, Naoyuki 国吉直行. Toshi dezain to kūkan enshutsu 都市デザインと空間演出 [Urban Design and Open Space Orchestration]. Shiriizu jichi o tsukuru シリーズ自治を創る, 6. Tōkyō: Gakuyō Shobō, 1989

Langer, Kerstin, and Bettina Oppermann. "Zur Qualität von Beteiligungsprozessen - 10 Eckpfeiler für das Projektmanagement.” In Praxis Bürgerbeteiligung. Ein Methodenhandbuch, edited by Astrid Ley and Ludwig Weitz. Bonn: Stiftung Mitarbeit - Agenda Transfer, 2003

Lehnen, Reinhard. Ermittlung gruppenspezifischer Erwartungen an raumrelevantes Handeln der Gemeinde: ein sozialgeographischer Beitrag zur Verbesserung von Bürgerbeteiligung und Methodik bei der Stadtentwicklungsplanung. Frankfurt am Main: Inst. für Wirtschafts- u. Sozialgeographie d. Johann Wolfgang Goethe-Universität, 1980

Mehlhorn, Dieter-Jürgen. Stadterhaltung als städtebauliche Aufgabe: Grundlage und Sicherung der Erhaltungsziele durch historisch-genetische Siedlungsanalyse und Bauleitplanung gem. BauGB. Düsseldorf: Werner, 1988 
Murahashi, Katsuhiko 村橋克彦. Yokohama machizukuri shimin katsudō no rekishi to genjō. Mirai o tenbō shite 横浜まちづくり市民活動の歴史と現状・未来を展望して [The History and Status quo of Citizenship Activities in City Planning in Yokohama. Vista of the Future]. Edited by Yokohama Shiritsu Daigaku 横浜市立大学 [Yokohama City University]. Tōkyō: Gakubunsha, 2009

Nishikawa, Yoshiaki 西川芳昭, Matsuo Tadasu 松尾匡 and Isa Atsushi 伊佐淳. “Sanka-gata hatten no rinen - shuhō to sono kadai” 参加型発展の理念・手法とその課題 [The Principle of Progress in Participation - Methods and Tasks]. In Shimin sanka no machizukuri. Sanka to riidāshippu. Jiritsu to pātonāshippu 市民参加のまちづくり。参加とリーダーシップ・自 立とパートナーシップ [Town Planning with Citizen Participation. Participation and Leadership - Autonomy and Partnership], edited by Matsuo Tadasu 松尾匡, Nishikawa Yoshiaki 西 川芳昭 and Isa Atsushi 伊佐淳. Tōkyō: Sōseisha, 2007, pp. 93-110 [1st edition 2005]

NTN (Nihon tōkei nenkan) 日本統計年鑑 [Japan Statistical Yearbook]. "Shi-chō-son-sū oyobi jinkō” 市町村数及び人口 [Number of Cities, Towns and Villages and Population]. Tōkyō: Japan Statistical Association, 2009 [59th edition 2010]

Reinert, Adrian. "Bürger(innen)beteiligung als Teil der lokalen Demokratie." In Praxis Bürgerbeteiligung. Ein Methodenhandbuch, edited by Astrid Ley and Ludwig Weitz. Bonn: Stiftung Mitarbeit - Agenda Transfer, 2003

Satō, Yoshinobu 佐藤快信. “Chiikizukuri ni okeru chiiki renkei to chiiki shigen” 地域づくりに おける地域連携と地域資源 [About District Co-operation and Resources in District Planning]. In Nagasaki Wesleyan University Journal, vol.1, March 2003, Isahaya (Nagasaki): Faculty of Contemporary Social Studies, Nagasaki Wesleyan University, 2003, pp. 1-7

Satō, Yoshinobu 佐藤快信. “Shimin sanka no machizukuri. Sanka, Sankaku, Shudō” 市民参加の まちづくり。参加・参画・主導 [Town Planning with Citizen Participation. Participation, Participatory Planning, Leadership]. In Shimin sanka no machizukuri, edited by Matsuo Tadasu 松尾匡, Nishikawa Yoshiaki 西川芳昭 and Isa Atsushi 伊佐淳. Tōkyō: Zōseisha, 2007, pp. 21-35 [1st edition 2005]

Seko, Kazuho 世古一穂 (Hg.). “Sanka to kyōdō no dezai” 参加と協働のデザイン [Design of Participation and Co-operation]. In Sanka to kyōdō no dezain. NPO - gyōsei - kigyō no yakuwari o saikō suru. NPO ・ 行政・企業の役割を再考する [Reconsidering the Role of the Non-Profit Organisation, Administration and Business], edited by Seko Kazuho 世古一穂. Kyōto: Gakugei, 2009, pp. 11-96,

Tanaka, Eiji 田中栄治. “Midori to suihen kūkan no saikōchiku” みどりと水辺空間の再構築 [The Reconstruction of Green and Waterside Open Spaces]. In Toshi dezain to kūkan enshutsu. 都市デザインと空閒演出 [Urban Design and Open Space Orchestration], edited by Kuniyoshi Naoyuki 国吉直行. Tōkyō: Gakuyō Shobō, 1989, pp.139-162 (=Shirīzu jichi o tsukuru; 6)

TCKGC (Takashima Chūō Kōen Gardening Club) [Takashima Central Park Gardening Club]. Yokohama Shimin Machibushin Jigyō. Dai ichiji seibi teian sho. 横浜町普請事業。第一次整 備提案書。[Yokohama City Construction Project. First Draft Proposal]. Yokohama: Takashima Central Park Gardening Club, 2008

TKCS (Toshi keikaku chūō shingikai) [Main Advisory Committee for City Planning]. "Kongo no toshi-seisaku wa ikani arubeki ka” 今後の都市政策は、いかにあるべきか, second report, 2000 (unpublished)

TKSK (Toshi kiban seibi kōdan) 都市基盤整備公団 [Society for Urban Development]. 2003. http://www.mof.go.jp/singikai/zaiseseido/tosin/zaitoa150625/09.pdf, accessed September 2010 
TKSK (Toshi kiban seibi kōdan) 都市基盤整備公団 [Society for Urban Development]. Minatomirai 21 Chūō chiku. Takashima chūō kōen. Kihon kōsō-kihon keikaku-hōkokuみなとみ らい 21 中央地区。高島中央公園。基本構想 - 基本計画 - 報告 [Downtown Minato Mirai 21. Takashima Central Park. Basic Concept - Preliminary Design - Report]. Yokohama: Toshi kiban seibi kōdan, 2004

Tsuchiya, Mamiko 土屋真美子. "Taitō na pātonāshippu ni motozuku 'kyōdō keiyaku' no arikata" 対等なパートナーシップに基づく「協働契約」のあり方 [The model of a 'co-operation agreement' based on partnership]. In Sanka to kyōdō no dezain. NPO - gyōsei-kigyō no yakuwari o saikō suru. 参加と協働のデザイン。NPO・行政・企業の役割を再考する [Reconsidering the Role of the Non-Profit Organisation, Administration and Business], edited by Seko Kazuho 世古一穂. Kyōto: Gakugei, 2009, pp. 172-192

Vetter, Angelika. Erfolgsbedingungen lokaler Bürgerbeteiligung. Städte und Regionen in Europa, 16. Wiesbaden: Verlag für Sozialwissenschaften, 2008

Vogt, Silke. Neue Wege der Stadtplanung - Partizipationsansätze auf der Mikroebene, dargestellt anhand ausgesuchter machizukuri Projekte in Tōkyō. Monographien aus dem Deutschen Institut für Japanstudien der Philipp Franz von Siebold Stiftung, 30. München: Iudicium, 2001

YKSK (Yokohama-shi kankyō sōzō-kyoku) 横浜市環境創造局 [Environmental Planning Office] "Kōen aigokai." 2010. http://www.city.yokohama.lg.jp/kankyo/park/aigokai/, accessed November 2010

YSKSC (Yokohama-shi shimin katsudō shien sentā) 横浜市市民活動支援センター [Civic Centre for Participation, Yokohama]. Yokohama shimin machibushin jigyō. Machibushin-bun 横浜 市民町普請事業。町普請文。[City Construction Project for Citizens of Yokohama. City Construction Report], no. 8, 2008.

http://www.city.yokohama.lg.jp/toshi/chiikimachi/machibushin/newspaper/200808.pdf, accessed September 2010

YSKSC (Yokohama-shi shimin katsudō shien sentā) 横浜市市民活動支援センター [Civic Centre for Participation, Yokohama]. Yokohama shimin machibushin jigyō. Machibushin-bun 横浜 市民町普請事業。町普請文。[City Construction Project for Citizens of Yokohama. City Construction Report], no. 10, 2009.

http://ww.city.yokohama.lg.jp/toshi/chiikimachi/machibushin/newspaper/200903.pdf, accessed September 2010

YSSK (Yokohama-shi shimin-kyoku) 横浜市市民局 [Department for Citizens of Yokohama]. Jūmin soshiki no genjō to katudō. Heisei 14nen do jichikai chōnaikai jittai chōsa hōkoku sho. 住民組織の現状と活動。平成 14 年度自治会町内会実態調査報告書。[Current State and Activities of Civil Associations. Inspection Report on the Current State of Self-Governed Corporate Bodies and Neighbourhood Associations in Heisei 14 (2003)] Yokohama: Yokohamashi shimin-kyoku, 2002

YTKK (Yokohama-shi toshi keikaku-kyoku) 横浜市都市計画局 [City Planning Department of Yokohama]. Miryoku aru toshi e. Toshi dezain hakusho 魅力ある都市へ。都市デザイン白 書 [To a City with Charm. White Paper on Urban Planning]. Yokohama: City of Yokohama, 1983

YTKK MM21 (Yokohama-shi toshi keikaku-kyoku Minato Mirai 21 tantō) 横浜市都市計画局み なとみらい 21 担当 [City Planning Department of Yokohama Minato Mirai 21 Office]. Minato Mirai 21. Yokohama. Yokohama: YTKK, 1989

YTSK (Yokohama-shi Toshi Seibi-kyoku) 横浜市都市整備局 [Department of City Organisation Yokohama]. “Takashima Chūō Kōen” 高島中央公園 [Takashima Central Park]. 2007. http://www.city.yokohama.jp/me/toshi/mm21/press/takashima.html, accessed April 2010 
YTSK (Yokohama-shi Toshi Seibi-kyoku) 横浜市都市整備局 [Department of City Organisation Yokohama]. Chiiki machizukuri hakusho 2009 地域街づくり白書 2009 [White Paper for District machizukuri]. Yokohama: City of Yokohama, 2009

YTSK (Yokohama-shi Toshi Seibi-kyoku) 横浜市都市整備局 [Department of City Organisation Yokohama]. “Heisei 20nendo niji kontesuto”平成 20 年度二次コンテスト [2008 (Heisei 20) Second Competition]. 2010a.

http://www.city.yokohama.lg.jp/toshi/chiikimachi/machibushin/20/2ndcon.html, accessed September 2010

YTSK (Yokohama-shi Toshi Seibi-kyoku) 横浜市都市整備局 [Department of City Organisation Yokohama]. “Heisei 20nendo seibi teian ichiran” 平成 20 年度整備提案一覧 [Diagram of the Planning Proposal 2008 (Heisei 20)]. 2010b. http://www.city.yokohama.lg.jp/toshi/chiikimachi/machibushin/20/, accessed September 2010 YTSK (Yokohama-shi Toshi Seibi-kyoku) 横浜市都市整備局 [Department of City Organisation Yokohama]. “Takashima Chūō Kōen” 高島中央公園 [Takashima Central Park]. 2010c. http://www.city.yokohama.lg.jp/toshi/mm21/press/pdf/takashima2.pdf, accessed August 2010 ZHY (Zaidan Hōjin Yokohama-shi furusato rekishi-zaidan) 財団法人横浜市古里歴史財団 [Incorporated Foundation of Yokohama for Homeland and History] (ed.). Kaikō 150shū-nen kinen. Yokohama rekishi to bunka 開港 150 周年記念。横浜歴史と文化 [150th Anniversary of Port Opening. The History and Culture of Yokohama]. Yokohama: Yūrindō, 2009 


\section{INTERVIEWS}

Horiuchi, Hiroyuki. Interviewed by author, Yokohama, July 29, 2010

Matsumoto, Michio. Interviewed by author, Yokohama, August 1, 2010

Minakuchi, Hidehiko, interview with author, Yokohama, July 29, 2010

Naitō, Noriko, interview with author, Yokohama, August 1, 2010

Ōkage, Naoko, interview with author, Yokohama, July 29, 2010

Sakai, Kazuhiro, interview with author, Yokohama, August 27, 2010

Tsukada, Yōichirō, interviewwith author, Yokohama, July 29, 2010

Uchida (the name was changed at the request of the interviewees in order to ensure anonymity), interview with author, Yokohama, August 6, 2010 


\section{GLOSSARY}

\begin{tabular}{|c|c|c|}
\hline aigokai & 愛護会 & $\begin{array}{l}\text { association for protection and } \\
\text { maintenance (mostly of parks) }\end{array}$ \\
\hline Amamiya (Mrs) & 天宮さん & $\begin{array}{l}\text { Citizen of Yokohama and partici- } \\
\text { pant in the workshops held in } 2003\end{array}$ \\
\hline Asukata Ichio & 飛鳥田 一雄 & $\begin{array}{l}(1915-1990) \text { former mayor of } \\
\text { Yokohama }\end{array}$ \\
\hline bunken & 分権 & decentralisation \\
\hline Ch'ang-an & 長安 & $\begin{array}{l}\text { Ch'ang-an (ancient capital city of } \\
\text { China, today known as Xi'an) }\end{array}$ \\
\hline Chihō bunken suishin-hō & 地方分権法 & Act to Advance Decentralisation \\
\hline $\begin{array}{l}\text { chiiki machizukuri; } \\
\text { chiikizukuri }\end{array}$ & $\begin{array}{l}\text { 地域まちづくり } \\
\text { 地域づくり }\end{array}$ & $\begin{array}{l}\text { regional urban planning with citi- } \\
\text { zen participation }\end{array}$ \\
\hline Chiiki machizukuri-ka & 地域まちづくり課 & $\begin{array}{l}\text { Department for District machizu- } \\
\text { kuri }\end{array}$ \\
\hline $\begin{array}{l}\text { Chiiki machizukuri kentō } \\
\text { iinkai }\end{array}$ & まちづくり検討委員会 & $\begin{array}{l}\text { Commission of Inquiry for District } \\
\text { machizukuri }\end{array}$ \\
\hline $\begin{array}{l}\text { chiiki machizukuri suishin } \\
\text { jōrei }\end{array}$ & 地域まちづくり推進条例 & $\begin{array}{l}\text { regulation to promote district } \\
\text { machizukuri }\end{array}$ \\
\hline chirashi & 散らし,チラシ & leaflet, flyer \\
\hline chōnaikai & 町内会 & neighbourhood association \\
\hline Chūō-ku & 中央区 & Chūō ward \\
\hline dokuritsu gyōsei hōjin & 独立行政法人 & self-regulatory body \\
\hline Edo-jidai & 江戸時代 & Edo period (1603-1868) \\
\hline Fukuyama-shi & 福山市 & City of Fukuyama \\
\hline gyōsei & 行政 & management, administration \\
\hline Gyōsei tetsuzuki-hō & 行政手続法 & Administrative Procedure Act \\
\hline han & 班 & group \\
\hline han-chō & 班長 & group leader \\
\hline Heian-kyō & 平安京 & Heian-kyō (former name of Kyōto) \\
\hline Heijō-kyō & 平城京 & Heijō-kyō (former name of Nara) \\
\hline Hiroshima-ken & 広島県 & Hiroshima Prefecture \\
\hline Horiuchi Hiroyuki & 堀内宏幸 & $\begin{array}{l}\text { head of the directorate of the De- } \\
\text { partment for District machizukuri } \\
\text { in the Department of City Organi- } \\
\text { sation in Yokohama }\end{array}$ \\
\hline jichikai / jichitai & 自治会 / 自治体 & self-governed corporate body \\
\hline jichikaichō & 自治会長 & $\begin{array}{l}\text { head of a self-governed corporate } \\
\text { body }\end{array}$ \\
\hline jigyō & 事業 & project, operation \\
\hline jimukyoku & 事務局 & secretariat \\
\hline jinji idō & 人事異動 & personnel restructuring \\
\hline jōka-machi & 城下町 & castle town \\
\hline jūmin & 住民 & resident \\
\hline jūmin sanka & 住民参加 ～～～～～～～～ & participation of residents \\
\hline $\begin{array}{l}\text { Kabushiki gaisha shibikku } \\
\text { dezain kenkyū jo }\end{array}$ & $\begin{array}{l}\text { 株式会社シビックデザイ } \\
\text { ン研究所 }\end{array}$ & Research Institute for Civil Design \\
\hline
\end{tabular}


Kabushiki gaisha Yokohama

Minato Mirai 21

kankyō hozen katsudō shien

Kankyō hozen-kyoku

Kankyō sōzō-kyoku

Kannai

keizoku-sei

Kenchiku-kyoku

Kenchiku-sen seido

Kinoshita Isamu

Kōbe
kōgyō
kōhō
Kokudo sōgō kaihatsu-hō
kokka kōmuin
kondankai
ku
kumi
kumin
kumin kaigi
kumin sanka
kumin sentā
kyōdō
kyōgikai
Kyōto
machizukuri

Matsumoto Michio

Matsuri

Meiji-jidai

Minaguchi Hidhiko

Minato Mirai 21

Minato Mirai 21 suishin-bu

Nagoya
株式会社横浜みなとみら い21

環境保全活動支援

環境保全局
環境創造局
関内
継続性
建築局
建築線制度
木下勇

神戸

工業

広報

国土総合開発法

国家公務員

懇談会

区

組

区民

区民会議

区民さんか

区民センター

協働

協議会

京都

街づくり、町づくり、ま ちづくり

松本道夫

祭り

明治時代

水口英彦

みなとみらい 21

みなとみらい 21 推進部

名古屋
Yokohama Minato Mirai 21 Jointstock Company programmes for environmental protection activities

Environmental Protection Agency

Environmental Planning Office

Kannai district

continuity

Building Authority

code for the alignment of buildings urban planner, landscape architect and professor at the University of Chiba

Kōbe (capital city of Hyōgo Prefecture)

industry

public information

Land Development Law

state officials

discussion, conference

district

group, set, team

residents of urban districts

citizens' consultation

participation by citizens of a $k u$

civic centre

co-operation

council meeting

Kyōto (ancient capital of Japan)

urban planning with citizen par-

ticipation

architect and chairman of the

Takashima Central Park Gardening

Club

festival

Meiji era (1868-1912)

assistant head of the directorate of the Department for District machizukuri in the Department of City

Organisation in Yokohama

Name of an urban expansion area in Yokohama

Department for the Promotion of Minato Mirai 21 area

Nagoya (major city in the Chūbu region of Japan) 
Naitō Noriko

Nara

Nishi-ku

Ōkage Naoko

Ōsaka

oyake

renzoku-sei

Sakai Kazuhiro

Setagaya-ku

shi

shi-chō-son

shi-chō-son no toshikeikaku

ni kansuru kihonteki hōshin

shimin

shimin katsudō

Shimin katsudō suishin

kentō iinkai

shimin-kyoku

shimin sanka

shimin undō

Shimizu (Mrs)

sofuto men

Takashima chūō kōen

famirii gāden

Takashima chūō kōen

gādeningu kurabu

Takashima chūō kōen

purojekuto

tatewari gyōsei

tochi kukaku seiri

tochi riyō

Tochi riyō keikaku

Tokugawa-jidai

Tōkyō

toshi dezain

toshikeikaku

Toshi keikaku-hō
内藤能里子

奈良

西区

大影直子

大阪

公

連続性

坂井和洋

世田谷区

市

市町村

市町村の都市計画に関す

る基本的方針

市民

市民活動

市民活動推進検討委員会

市民局

市民参加

市民運動

清水さん

ソフト面

高島中央公園ファミリ

一・ガーデン

高島中央公園・ガーデニ ング・クラブ

高島中央公園プロジェク 卜

縦割り行政

土地区画整理

土地利用

土地利用計画

徳川時代

東京

都市デザイン

都市計画

都市計画法 landscape architect and member of the Takashima Central Park Gardening Club

Nara (ancient capital of Japan)

Nishi district

assistant head of the Department

for District machizukuri in the

Department of City Organisation in

Yokohama

Ôsaka (city in the Kansai region in Japan)

public

continuity

head of the directorate of the Environmental Planning Agency in

Yokohama

Setagaya district

city, part of a city

municipalities

municipal master plan

resident of a shi, citizen

civic engagement, citizen initia-

tives

Commission for the Advancement

of Civic Engagement

local public office

citizen participation

citizens' movement or initiative

citizen of Yokohama and partici-

pant in the workshops held in 2003

soft surface

Family Garden in Takashima

Central Park

Takashima Central Park Gardening Club

Takashima Central Park Project

vertical fragmentation of management

reallocation of building land

land use

Land Use Plan

Tokugawa period (1603-1868)

Tōkyō (capital of Japan)

city design

urban planning

Town Planning Act 
Toshi keikaku-kyoku

Toshi kiban seibi-kōdan

Toshi saisei kikō

Tsukada Yōichirō

Toshi seibi-kyoku

undō

Yokohama

Yokohama cōdo

Yokohama-shi ryokusei-

kyoku

Yokohama-shi ryokuseikyoku kōen-bu keikaku-ka

Yokohama-shi toshi kei-

kaku-kyoku

Yokohama-shi kankyō sōzōkyoku

Yokohama-shi toshi seibi-

kyoku

Yokohama-shi shimin-kyoku

Yokohama Shimin Machibushin Jigyō

Yōto chiiki seido
都市計画局

都市基盤整備公団

都市再生機構

塚田洋一

都市整備局

運動

横浜

横浜コード

横浜市緑政局

横浜市緑政局公園部計画 課

横浜市都市計画局

横浜市環境創造局

横浜市都市整備局

横浜市市民局

ヨコハマ市民町普請事業

用途地域制度
City Planning Department

Society for Urban Development

(superseded)

Society for Urban Regeneration assistant head of the Department for District machizukuri in the Department of City Organisation in Yokohama

Department of City Organisation movement

Yokohama (capital city of Kanagawa Prefecture in Japan, located in the Kantō region)

Yokohama Code

Office of Greening (former name of Environmental Planning Office of Yokohama)

Division of Park Planning in the

Office of Greening

City Planning Department of Yokohama (since 2005 Department of City Organisation Yokohama)

Environmental Planning Office of the City of Yokohama

Department of City Organisation

Yokohama

Department for Citizens of Yokohama

City Construction Project for citizens of Yokohama

Land Use Zoning Plan 